率かつ自然な歩行を目指して，身体系のダイナミクスを活用した「ダイナミクスベースト制御」が注目を集めている。この思想に 基づき，さまざまな研究が行われているが，その中でも受動歩行を規範とした制御法が着目されている. 受動歩行機械は, 能動的 なアクチュエーションを必要とせず，重力や慣性力のみを利用して緩斜面を歩き下るロボットである。物理法則のみに従った挙動 であるため，エネルギ効率が高く，自然な歩行を可能とするヒューマノイドロボットの实現につながる技術として期待されている。 一方, 歩行と異なり走行に执いては, 身体系ダイナミクスが支配的になることが知られている。つまり，低速から中高速領域一と移 行するにつれて，センサフィードバックの役割が小さくなり，関節部に実装されるバネ・ダンパといった受動要素から生み出され る自己安定化作用が極めて重要な役割を果たす。そそのため，走行を実現する二脚歩行ロボットにおいては，低速領域の歩行以上に 身体系ダイナミクスが重要となる，そのため，本研究では，走行の実現において中核的な役割を果たすことが期街される，二脚受 動走行機械の構築を試みる。既存研究のシミュレーションにおいては，いわゆるコンパス型の単純な身体亲モデルが用いられてい た。しかしながら，足部分を無質量とし足の慣性を無効化している点や，自然な走行で観察される「両脚支持期がなく，画脚跳躍期 が存在する」という特徴が実現されていない，といった問題点が存在する，そこで本稿では，上トの走行パターンに近い受動走行 機械の実現を目的とする。このため，膝関節を有するモデルを扱う。受動走行機械の設計においては，多数のボディパラメータを 最適化する作業が必要となる。このため本研究では, 汎用ダイナミクスシミュレータ上に二朋受動走行機械を構築し, 進化的計算 手法を用いて構成論的にボディパラメータの最適化を行った。シミュレーションの結果, ヒトに類似した自然な走行が寒現できた。

\title{
1P1-L1-52 差分方程式による受動歩行の平衡点とその安定構造の解析
}

○池俣 吉人 (名工大), 佐野明人 (名工大), 藤本 英雄 (名工大)

Analysis of fixed point and its stable structure in passive walking from difference equation

OIkemata.Y (Nagoya Institute of Technology), Sano.A (Nagoya Institute of Technology), Fujimoto.H (Nagoya Institute of Technology)

1990 年に McGeer よって見出された受動歩行は，現在でも多くの研究者の興味を惹いている。適切な初期状態を与えると一 定の歩容に收束し，スロープの角度が上がると歩行周期が分岐して，最終的にカオス的な振る舞いを起こす，それぞれ「引き込み 現象」「分岐現象」と呼ばれる。引き込み現象は, 安定したリミットサイクルが存在することによって発生する. 分岐現象は, 又 ロープ角度が上がると、この安定な軌道が不安定に変化し, 状態が別の安定な軌道に遷移することによって生じる, つまり, 引き 込み現象と分岐現象は，リミットサイクルの安定性が起因となって発生する。このことから，リミットサイクルの力学的メカニズ ムが受動歩行の重要な本質の一つと考えられる，本研究では，離散力学的な観点から差分方程式を導出し，リミットサイクルの一 断面の点である平衡点とその安定となるメカニズムについて解析する。 また，物理現象を解析する上で，対象物を簡易化して考え ることは有効な手段となる，そこで，本研究では，まず受動歩行を簡易化したモデルについて解析を行う。そして，そこで得られ た知見をもとに受動歩行について議論する.

\section{P1-L1-53 受動的歩行における着地衝撃力利用に関する研究}

○藤岡 美博 (松江高専)

A Study of Use of an Impulsive Force at the Impact of the Leg with the Ground on Passive Walking

OFujioka.Y (Matsue N.C.T.)

2 足歩行ロボットの効率よい歩行方法として，受動的歩行がある。この歩行は，歩行時のエネルギ損失が遊脚と床面との衝笑時 に起こるという点で効率がよいものである。ただし，外力を全く加えない場合には，斜面のみが歩行可能であり，この久点を補う ためさまざまな制御手法などが提案されている，ただし，ほとんどの研究はコンパス型ロボットの機構はそのままで，制御手法に 関するものが多いため，遊脚と床面の衝突を歩行エネルギに変換するというものは，筆者の知るところまだない，そこで本研究で は，機構開発も同時に進めながら，遊脚が着地する際に床面から受ける撃力を歩行のための推進力として利用することを考え，そ の実現可能性について検証する，本研究では，研究の第一歩として，撃力をそのまま回転トルクとして利用した場合について考察 を行ったので報告する.

\section{P1-L1-54 ポアンカレ写像に基づく準受動的歩行のロバスト制御器の設計とその効果}

○人保 仁 (京都大), 大須賀 公一 (神戸大), 藤本 健治 (名古屋大)

The Design of the Robust Controller of a Semi-Passive Dynamic Walk based on a Poincare Map and the Effect by the Controller

OKubo.H (Kyoto univ.), Osuka.K (Kobe univ.), Fujimoto.K (Nagoya univ.)

本稿では 2 足歩行ロボットの衝突点に関するポアンカレ写像を用いて線形近似離散モデルを構築し，これを用いてロバストコン トローラを設㖕する。このコントローラを用いたときの安定歩行へ引き込まれる衝突点集合の変化と外乱が存在したときの入力の 様子について調バる。これらより, 遅延フィードバック制御が歩行ロボットに与える影響とロバストコントローラの効果を確認寸 る。またここれらの結果から準受動的歩行を実現する「歩容監視型遅延フィードバック制御」を提案する.

1P1-L1-55 受動歩行における Foot Scuffing 現象と足裏形状との関係に関する一考察

○小 崇之 (横浜国大), 杉内 肇 (横浜国大), 藪田 哲郎 (横浜国大)

Consideration concerning the relation of the Foot Scuffing and Sole Form in a Passive Dynamic Walking.

OKoyama.T (Yokohama National Univ.), Sugiuchi.H (Yokohama National Univ.), Yabuta.T (Yokohama National Univ.) 
二足歩行運動のシミュレーション解析において，より実環境に近い環境構築実現の為には，人間の足裹の様に柔らかいものを扱 える弾性衝突を考慮したシミュレーターが有効であると思われる。そこで，本研究では，ばね・ダンパモデルを用いた三次元動力 学シミュレーター (HSIM2) 及び GUI を開発し，これを用いて受動的歩行シミュレーション赛験を行った．最も単純なもデルで あるコンパス型ロボットの受動的歩行において, Foot Scuffing 現象があるが，これによって点接触モデルでは安定的な歩行は困 難であることを示し，解決策として考えられる足裏形状が歩行安定性に及ぼす影響を考察した。

\section{P1-L1-56 連続型 DFCによる準受動的歩行ロボットQuartetIII の歩行実験}

○杉本 靖博 (京大), 大須賀 公一 (神戸大)

Walking Experiment of Quasi-Passive-Walking-Robot QuartetIII via continuous-DFC OSugimoto.Y (Kyoto Univ.), Osuka.K (Kobe Univ.)

本発表では, 以前提案した準受動的歩行の安定化制御則を, 受動的歩行の研究のために製作された歩行ロボットQuartetIIIに 実際に用いて歩行実験を行ない, その有効性を確認する. 用いる制御則は, 以前提案されている弱誘導制御および遅延フィード バック制御 (DFC) に基づく制御を, それぞれの利点を活かしつつうまく組み合わせたものとなっており，二つの大きな特徽を 持っている.一つめの特徵としては, 前もって作った目標軌道ではなく, 一路前にロボットが描いた軌道に対し追従制御をすると いう点が举げられ，これは連続型の DFC を行うことに他ならないものである. 二つ目の特徵としては, 追従制御を行なう際のゲ インを歩行の安定性に応じて変化させているという点が挙げられる.

\section{歩行ロボット 2}

\section{P1-L1-57 1 脚， 2 脚， 4 脚ロボットの平面受動走行}

○立 相昊 (東北大), 姜 欣 (東北大), 江村 超 (東北大)

Passive running of planar 1/2/4-legged robots

OHyon.S (Tohoku Univ.), Jiang.X (Tohoku Univ.), Emura.T (Tohoku Univ.)

本論文は著者等がこれまで行ってきた平面 1 脚，2 脚走行ロボットの歩容解析および安定化制御について紹介するとともに, 新 たに得られた平面 4 脚走行ロボットの受動走行について報告する. 1 脚ロボットについては受動走行を数值的に探索し, 自明な解 を除いて全ての走行が不安定であることを示寸。また 2 つ軌道安定化制御則を提案し，とくに遅延つィードバック制御によって 受動走行軌道が安定化されることを示す.胴体を有する 2 脚ロボットでは受動走行軌道が得られなうため, 接地期に㧍ける姿勢制 御を追加し， 1 脚ロボットの遅延フィードバック制御を適用した結果, 安定な 2 脚走行が得られることを示す. 4 脚ロボットでは受 動走行軌道を数值的に探索し，2つの典型的なバウンス走行を示す．また，それらの安定性や対称性などの性質についても述べる。

1P1-L1-58 パラレルリンクを使用した 4 足歩行ロボットの開発

○加納 健良 (近畿大), 山本 昌彦 (近畿大), 大坪 義一 (近畿大), 藤井 康夫 ((株) ロボメカニクス研 究所)

Development of a quadruped walking robot with parallel link

OKano.T (Kinkiuniv), Yamamoto.M (Kinkiuniv), Ohtsubo.Y (Kinkiuniv), Fujii.Y (RRI)

我々は, 構造的に高剛性, 多自由度, 高精度を有寸るリンクの並列結合によるパラレルリンクを使用した作業移動型ロボットを 提案する. 提案するロボットは， 6 本のアクチュエータからなる 6 軸パラレルリンクを直列結合した 2 本のマニピュレータと 3 本 のアクチュエータからなる 3 軸パラレルリンクを使用した 4 足歩行ロボットである. 精度の高い伸縮動作の可能なパラレルリンク を脚部に使用することによって，不整地での凹凸面を正確に捕らえ，より安定した歩行が可能であると考えられる．本稿では，そ の移動機構である 4 足歩行ロボットの構造を説明し, 運動学から導かれた可動範囲を示寸。そして, 整地での静歩行を想定した動 作検証を行った。本ロボットは, 原子炉内や災害地等に代表される人間が立ち入ることが困難な現場や, 老人や身体障害者の助计 になる福祉の現場での活躍が期待できる.

1P1-L1-59 操作者の操作能力に適応する脚型ロボットシステム

一遠隔操作におけるローカル補正制御一

○五十嵐 洋 (東京電機大), 原島 文雄 (東京電機大), 柿倉 正義 (東京電機大)

Walking Robot System with Operator's Ability

- Local Control for Remote Operation -

OIgarashi.H (Tokyo Denki Univ.), Harashima.F (Tokyo Denki Univ.), Kakikura.M (Tokyo Denki Univ.)

ロボットの遠隔操縦に関するさまざまな研究が行われているが，操作者の操作能力については考慮したものは少ない，ところが， 操作者のスキルや特性などは一定ではなく, 習熟により変化する可能性もあるため, 操作能力に適応するシステムが望ましいと考 えられる.この点に着目したシステム設計概念として Human Adaptive Mechatronics (HAM) が提案されている. 本研究は, HAM に基づく複数台の脚型ロボットによる遠隔搬送システムの実現を目的としている．このようなアプリケーションに㧈いて， 4 脚ロボットには脚型特有の問題である安定性や可動限界拘束などを改善し，操作者をサポートする機能が要求される，本稿では， システム実現の第一段階として, 脚型ロボットの遠隔操作を奏現させるための安定および可動限界制約のローカル補正手法を提案 する.これにより，操作者が見落としやすい段差などの比較的小さな障害物の乗り越え動作を操作者が高さ方问成分を意識するこ と無く実現することが期待できる。本稿では，実験によりローカル補正機能を検証する． 